\title{
Cartridge Dosing Unit
}

National Cancer Institute

\section{Source}

National Cancer Institute. Cartridge Dosing Unit. NCI Thesaurus. Code C48481.

A dosing unit equal to the amount of active ing redient(s) contained in a cartridge. 